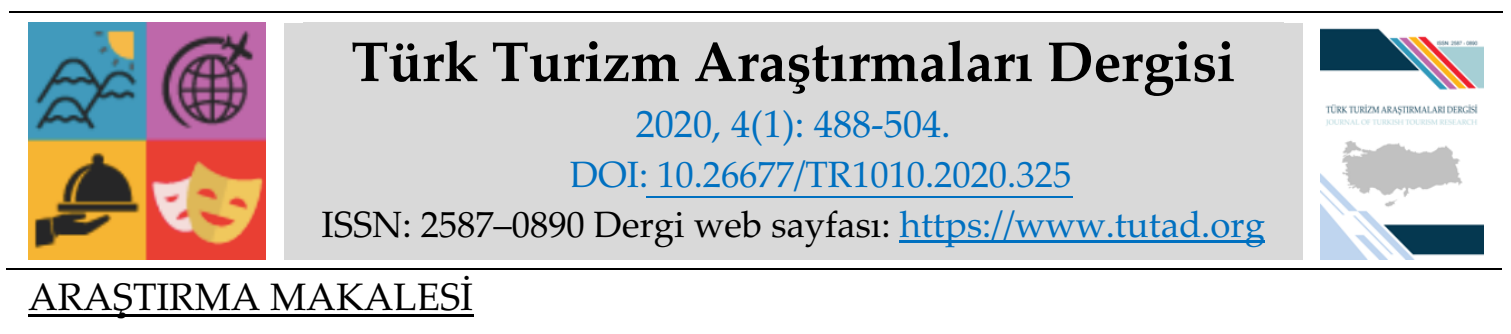

\title{
Bir Hüzün Turizmi Destinasyonu Olarak Ulucanlar Cezaevi Müzesi Ziyaretçilerinin Elektronik Yorumlarının İçerik Analizi
}

Dr. Öğr. Üyesi Serkan AYLAN, Karamanoğlu Mehmetbey Üniversitesi, Uygulamalı Bilimler Yüksekokulu, Karaman, e-posta: serkaylan@gmail.com

ORCID: https://orcid.org/0000-0002-7262-4440

Prof. Dr. İsmet KAYA, Karamanoğlu Mehmetbey Üniversitesi, Uygulamalı Bilimler Yüksekokulu, Karaman, e-posta: ismetkaya99@yahoo.com

ORCID: https://orcid.org/0000-0002-9664-3160

Öz

$\mathrm{Bu}$ araştırmanın amacı Ankara'da yer alan tarihi Ulucanlar Cezaevi Müzesi ile ilgili tripadvisor.com internet sitesinde yer alan, müzeyi ziyaret eden ziyaretçilerin yorumlarını çözümleyerek, ziyaretçilerin hissettikleri duygu türlerini, memnuniyet düzeylerini ve tavsiyelerini tespit etmektir. Araştırmanın verileri popüler bir sosyal paylaşım sitesi olan TripAdvisor seyahat sitesinden alınmıştır. Eylül 2013'ten Temmuz 2019'a kadar www.tripadvisor.com linkinde yer alan 317 yorum bir kelime işlem programı olan word ortamına aktarılmış ve nitel araştırma yöntemlerinden biri olan içerik analizine tabi tutulmuştur. Araştırma kapsamında verileri analiz etmede MAXQDA 18 programından yararlanılmıştır. 317 yoruma yapılan içerik analizinde yorumlar, "turist beklentisi", "hissedilen duygu", "tavsiye," ve "diğer" yorumlar olmak 4 temel tema altında gruplandırılmış ve kodlanmıştır. Elde edilen bulgulara bakıldığında, ziyaretçilerin çoğunluğu müzeyi beğendiğini ve ziyaretten memnun kaldığını belirtmiştir. Ayrıca müzeyi daha sonra ziyaret edecek potansiyel ziyaretçilerce, müzenin mutlaka görülmesi gerektiği yönünde ve müze yönetimine de alanda fiziksel imkanların artırılması gerektiği yönünde önerilerde bulunmuşlardır. Ziyaretçilerin ziyaret sonrası hissettikleri duyguların ise çoğunlukla etkileyici, hüzün ve korku ağırlıklı duygular olduğu görülmektedir.

Anahtar Kelimeler: Hüzün Turizmi, MAXQDA, İçerik Analizi, Tripadvisor.

Makale Gönderme Tarihi: 31.10.2019

Makale Kabul Tarihi: 12.01 .2020

\section{Önerilen Atıf:}

Aylan, S. ve Kaya, İ. (2020). Bir Hüzün Turizmi Destinasyonu Olarak Ulucanlar Cezaevi Müzesi Ziyaretçilerinin Elektronik Yorumlarının İçerik Analizi, Türk Turizm Araştırmaları Dergisi, 4(1): 488-504.

(C) 2020 Türk Turizm Araştırmaları Dergisi. 


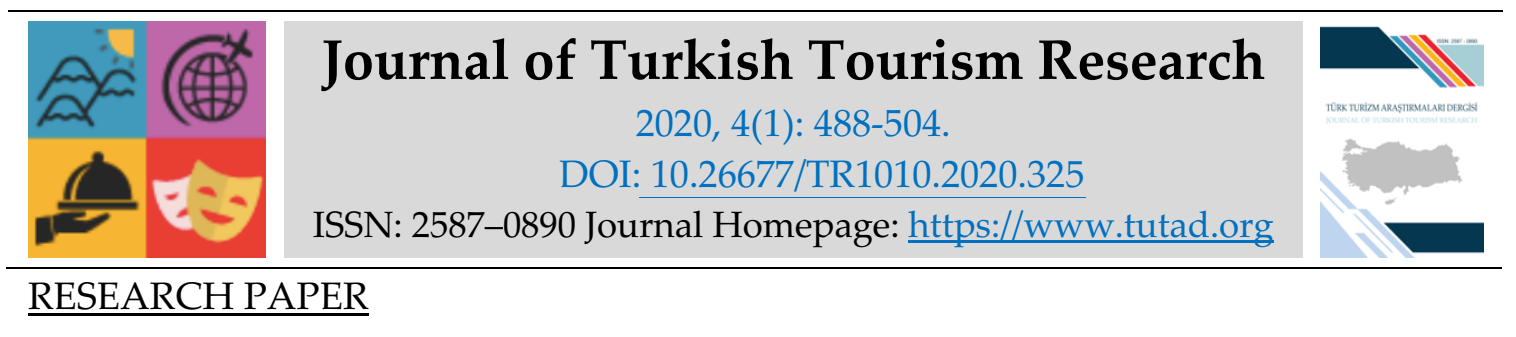

\title{
Content Analysis of Electronic Comments of Ulucanlar Prison MuseumVisitors as a Destination of Dark Tourism
}

Assistant Prof. Dr. Serkan AYLAN, Karamanoğlu Mehmetbey University, School of Applied Sciences, Karaman, e-mail: serkaylan@gmail.com

ORCID: https://orcid.org/0000-0002-7262-4440

Prof. Dr. İsmet KAYA, Karamanoğlu Mehmetbey University, School of Applied Sciences, Karaman, e-mail: ismetkaya99@yahoo.com

ORCID: https://orcid.org/0000-0002-9664-3160

\begin{abstract}
The purpose of this study is to determine the types of feelings, satisfaction levels and recommendations of the visitors by analyzing the comments of visitors who visit the museum on tripadvisor.com website about the historical Ulucanlar Prison Museum in Ankara. The data of the research was drawn from the TripAdvisor travel site, which constitutes the largest online network of traveling consumers. From September 2013 to July 2019, 317 comments on tripadvisor.com were transferred to Word and subjected to content analysis, one of the qualitative research methods. MAXQDA 18 program was used to analyze the data. In the content analysis of 317 comments, the comments were grouped and coded under 4 main themes: "tourist expectation", "sensed feeling", "advice," and "other" comments. According to the findings of study, the majority of the visitors liked the museum and were satisfied with the visit. They also advise potential visitors who will visit the museum later that the museum should be seen and advice museum management that the physical facilities of the museum should be increased. On the other hand, the emotions that the visitors feel after the visit are mostly impressive, sadness and fear. When all these findings are evaluated, it can be said that Ulucanlar Prison Museum has an important dark tourism potential.
\end{abstract}

Keywords: Dark Tourism, MAXQDA, Content Analysis, Tripadvisor.

Received: 31.10 .2019

Accepted: 12.01 .2020

\section{Suggested Citation:}

Aylan, S. and Kaya, İ. (2020). Content Analysis of Electronic Comments of Ulucanlar Prison MuseumVisitors as a Destination of Dark Tourism, Journal of Turkish Tourism Research, 4(1): 488504.

(C) 2020 Türk Turizm Araştırmaları Dergisi. 


\section{GİRIŞ}

Hüzün turizmi ilk çağlardan beri hüzün yaşayarak haz alma duygusu için bu tür mekanları ziyaret etmek isteyen insanların istek ve taleplerinin organize bir şekilde ekonomik ve ticari faaliyetlere yansıtılması sonucu ortaya çıkan, özel ilgi ve kültürel miras turizmi kapsamında değerlendirilen bir alternatif turizm biçimidir (Trauer, 2006; Niemelä, 2010; Kılıç ve Akyurt, 2011; Bozok vd., 2014, Yıldız vd., 2015; Hartmann, 2014; Alili, 2017). Bugün Türkiye'de ve dünyada trajedik olayların yaşandığı yerleri ziyaret eden insanların sayısı dikkate değer bir şekilde artmıştır. Her yıl 1,4 milyon insanın ziyaret ettiği Auschwitz soykırım kampı, yılda 1 milyon kişinin ziyaret ettiği Ground Zero anıtı, açıldığından günümüze kadar 53 milyon kişi tarafından ziyaret edilen Hiroshima Barış Anıtı Parkı Müzesi (Fonseca vd., 2016), 2018 yılında 6,5 milyona yakın ziyaretçi çeken Anıtkabir (www.anitkabir.tsk.tr), yine 2015 yılında 800 bine yakın kişinin ziyaret ettiği Gelibolu Tarihi Milli Parkı (Alili, 2017) hüzün turizmine katılan ziyaretçilerin sayısal olarak önemli boyutlara ulaştı̆̆ını gösteren örnekler olarak gösterilebilir. Bu çalışmanın konusu olan Ulucanlar Cezaevini Müzesin'i ise açıldığı 2011 yılından beri 1,5 milyondan fazla kişi ziyaret etmiştir.

Hüzün turizmine olan bu yüksek talep turizmin on iki aya yayılması açısından büyük bir avantaj sağlamakta, zira bu tür ziyaretlerde mevsimsellik faktörünün ziyaretler üzerinde etkisi çok az olmaktadır. Bu durum, belirli zamanlarda ve mekanlarda yoğunlaşan turizm faaliyetlerinin çevresel, sosyo-kültürel ve ekonomik baskılarını hafifletme ve turizmin sürdürülebilirliği açısından önemli bir alternatif sunmaktadır.

Çalışmada konunun iyi anlaşılabilmesi açısından öncelikle hüzün turizmi ile ilgili çeşitli yaklaşımlar ele alınmış, hüzün turizmi ile ilgili kavram kargaşasına değinilmiş, hüzün turizminin, özel ilgi ve kültürel miras turizmi ile bağlantısı analiz edilmiştir. Daha sonra dünyada ve Türkiye'de önemli hüzün turizmi alanlarına yer verilmiştir. Sonrasında Türkiye'deki hüzün turizmi noktalarından biri olan Ulucanlar cezaevini ziyaret eden ziyaretçilerin tripadvisor.com sitesinde yapmış oldukları yorumlar incelenmiş, söz konusu yorum kod-alt kodlara ayrılarak içerik analizine tabi tutulmuştur.

\section{KAVRAMSAL ÇERÇEVE}

Turizm alanında ortaya yeni çıkan alternatif yaklaşımlar ve kavramlar birkaç nedenden dolayı zamanla meydana gelmekte, şekillenmekte ve daha sonra genel kabul görmeye başlamaktadır. Bunlardan biri de eskiden beri toplumda var olan davranış biçimlerinin, yaşam tarzlarının ve tercihlerinin zaman içinde ticari bir nitelik kazanarak turizm organizasyonları ve faaliyetleri kapsamında değerlendirilmesidir. Örneğin, eski zamanlardan beri acı ve tradejilerin yaşandığ1 yerlere yapılan ziyaretlerin, üzüntü ve korkuların özellikle postmodern dönemde metalaşması sonucu ortaya çıkan turistik faaliyetler hüzün turizmi kapsamı içinde değerlendirilmiştir (Lennon ve Foley, 2000; Tarlow, 2007). Eski zamanlardan günümüze kadar insanoğlu ölümlerin, tradejilerin, insanı üzen olayların gerçekleştiği yerleri ziyaret etmektedirler. Eski Yunanlıların ve Romalıların firavun mezarların ziyaret etmeleri, M.Ö. 264 yılında düzenlenmeye başlanan gladyatör oyunları ve vahşi hayvanlarla yapılan döğüşlerin halka açık olarak Roma'da Collesium'da (Flavian amfitiyatrosu) ve benzer şekilde atlı araba yarışlarının Circus Maximus'da (Büyük Hipodrom) düzenlenmeye başlanması, yine M.Ö. 16 yy.da Mısırda yapılan idamların halka açık olarak gerçekleşmesi, 1838 yılında İngiltere'de iki idamın izlenmesi için rehberli tren yolculuğunun düzenlenmesi, İngiltere'de Victoria döneminde rehberli morg turlarının gerçekleştirlmesi ve kırbaçlanan mahkûmların izlenebilmesi için ziyaretçilere galerilerin kiralanması, eskiden beri dini alanlara yapılan düzenli haç ziyaretleri, 
hüzün turizmine verilebilecek ilk örnekler arasında gösterilmektedir (Foley ve Lennon, 2000; Kavraz, 2018; Kurnaz vd., 2013; Stone, 2006; Stone, 2013; Stone ve Sharpley, 2008; Uzunaraslan, 2005; Yildız, 2015).

Lennon ve Foley 1990' ların ortasından itibaren hüzün turizmi kavramını (dark tourism) ilk kullanan yazarlar olmuştur. Seaton 1996'da bunu "thanatourism" olarak kullanmıştır. "Dark" kelimesi karanlık, aydınlığın olmadığı yer, kum ve güneşin karşıtı gibi anlamlara sahip olmakla beraber savaş, soykırım, cinayet gibi karanlık işleri de ifade etmektedir (Bowman ve Pezzullo, 2009). Bu bağlamda, ölümle, tradejik olaylarla ilgili çekiciliklerin söz konusu olduğu turizm çeşidi yabancı literatürde "dark tourism" (hüzün turizmi) olarak nitelendirilmiştir (Lennon ve Foley, 2000; Tarlow, 2005). Seaton (1999) hüzün turizminin ölümle sembolik ya da gerçek olarak karşılaşma arzusu tarafından karakterize edilen bir turizm formu olduğunu söylemektedir. Toplumların ve dünyanın tarihine damga vurmuş önemli savaş, soykırım, felaket ve doğal afetler, yoksulluk, işkenceler, teknolojik felaketler ve ünlülerin ölümleri gibi olayların gerçekleştiği alanlara yapılan seyahatler hüzün turizmi kapsamında değerlendirilmektedir (Alili, 2017). Ancak, tradejik olayların hüzün turizmine dahil olabilmesi için eğitici olması ve ticari olarak kullanılabilmeleri gerekmektedir (Alaeddinoğlu ve Aliağaoğlu, 2007, Farmaki, 2013, Niemala, 2010).

Tablo 1. Hüzün Turizmi ile İlgili En Çok Kullanılan Kavramlar

\begin{tabular}{|c|c|c|c|}
\hline \multicolumn{2}{|c|}{ Yabancı Literatür } & \multicolumn{2}{|c|}{ Yerli Literatür } \\
\hline Kavramlar & Yazarlar ve Calışmanın yılı & Kavramlar & Yazarlar ve Calışmanın yılı \\
\hline $\begin{array}{l}\text { Dark } \\
\text { Tourism }\end{array}$ & $\begin{array}{l}\text { Bowman ve Pezzullo, 2009; } \\
\text { Foley ve Lennon, 1996, 2000; } \\
\text { Miles, 2002; Stone; 2006; } \\
\text { Stone ve Sharpley, 2008; } \\
\text { Strange ve Kampa, 2003; } \\
\text { Stone, 2006, 2010; 2012, 2013; } \\
\text { Tarlow, } 2007\end{array}$ & $\begin{array}{l}\text { Hüzün } \\
\text { Turizmi }\end{array}$ & $\begin{array}{l}\text { Alili, 2017; Birdir vd., 2015; } \\
\text { Çelik, 2017; Kılıç ve Akyurt, } \\
\text { 2011; Kılıç ve Sop, 2011; } \\
\text { Kurnaz vd., 2013; }\end{array}$ \\
\hline $\begin{array}{l}\text { Thana } \\
\text { Tourism }\end{array}$ & $\begin{array}{l}\text { Dann ve Seaton, 2013; } \\
\text { Dunkley, 2007; Friedrich ve } \\
\text { Johnston, 2013; Hartmann, } \\
\text { 2014; Knudsen, 2011; Lee } \\
\text { vd., 2012; Light, 2017; } \\
\text { Seaton, 1996; Seaton ve } \\
\text { Lennon, 2004; Slade, 2003; } \\
\text { Tzanelli, 2016 }\end{array}$ & - & - \\
\hline $\begin{array}{l}\text { Battlefield } \\
\text { Tourism }\end{array}$ & $\begin{array}{l}\text { Dunkley vd., 2011; Holguin, } \\
\text { 2005; Kuo vd., 2016; Lloyd, } \\
\text { 2014; Miles, 2014; Zhang, } \\
2010\end{array}$ & $\begin{array}{l}\text { Savaş } \\
\text { Alanları } \\
\text { Turizmi }\end{array}$ & $\begin{array}{l}\text { Alaeddinoğlu ve Aliağaoğlu, } \\
\text { 2007; Atay ve Yeşildağ, 2010; } \\
\text { Doğaner, 2006; Ilgar; 2015; } \\
\text { Okuyucu ve Erol, 2018; } \\
\text { Yeşildağ, } 2010\end{array}$ \\
\hline $\begin{array}{l}\text { Grief } \\
\text { Tourism }\end{array}$ & $\begin{array}{l}\text { Lewis, 2008; Slayton, 2006; } \\
\text { Tonner, } 2011\end{array}$ & - & - \\
\hline
\end{tabular}

Kaynak: Yazarlar tarafından derlenmiştir.

Hüzün turizmi ile ilgili kavramlara bakıldığında; farklı, ama birbirine yakın terimler altında kavramsallaştırıldığı görülmektedir. Ölüm, acı, tradeji, suç ve gaddarlıkla ilgili kavramların yer 
aldığı herhangi bir turizm faaliyetinin hüzün (dark) turizmi içinde yer aldığı, hüzün kelimesinin şemsiye kavramı görevini gördüğ̈̈, diğer kavramların onun altında yer aldığ savunulmaktadır (Light, 2017). Yabancı literatürde en fazla kullanılan kavramların "dark tourism", "thana tourism" ve "battlefield tourism" kavramları olduğu, yerli literatürde ise genelde "hüzün turizmi" ve "savaş alanları turizmi" kavramlarının tercih edildikleri göze çarpmaktadır "dark tourism" ile "thanatourism" kavramları arasındaki temel fark, "thana" kavramında ziyaret edilen yerlerdeki ölümlerin ve trajik olayların "dark" kavramına göre daha acımasız ve şiddetli gerçekleştiğini ifade etmesinde yatmaktadır. Dolayısyla "thanatourism" olarak adlandırılan hüzün turizminde ziyaretçi duyguları daha yoğun yaşanmaktadır (Light, 2017).

\section{Hüzün Turizminin Sınıflandırılması, Özel İlgi Turizmi ve Kültürel Miras Turizmi ile İlişkisi}

Tradejik olay ve ölümlerin gerçekleştiği yerlerin ve meydana gelen olayların niteliğine göre hüzün turizmine yönelik seyahetler beş kategoride gerçekleşmektedir (Seaton, 1999; Stone, 2006).

- $\quad$ Halka açık idamlara tanıklık etmek (günümüzde pek az görülmektedir) ya da ölüme tanıklık etmek (örneğin batmış feribotların ya da düşmüşs uçakların, terör sonucu meydana gelen patlamaların olduğu alanların ziyaret edilmesi, eski zamanlarda gladyatör oyunlarının izlenmesi gibi)

- $\quad$ Bireysel ya da kitlesel ölümlerin gerçekleştiği yerlere yapılan seyahatler (Gelibolu yarımadası gibi, oldukça büyük alanları kapsamaktadır, ölüm kampları, ölüm tarlaları, volkan patlamaları vb. kenneddy suikastının yapıldığı alan, Elvis presley gibi)

- $\quad$ Müzeler gibi ölümü temsil eden sembolik eşyaların, kalıntıların ve kanıtların bulunduğu yerlere yapılan seyahatler

- $\quad$ Ölümün canlandırıldığı ya da simule edildiği mekanlara yapılan seyahatler (Hz. İsa'nın çarmıha gerildiğinin temsil edilmesi gibi).

- Mezarlıklar, anıt mezarlar, savaş anıtları ve hapishaneler gibi alanları görmek için yapılan seyahatler.

Bunlara ilave olarak, intihar etmek için gidilen yerlerin, kıyamet günü turizmi, hayalet avcıllğ 1 turizmi ve yoksulluk turizminin de hüzün turizmi kapsamında değerlendirilmesi gerektiği öne sürülmektedir (Alili, 2017, Çelik, 2017).

Yıldız vd. (2015), hüzün turizmini çıkış ve oluşum kaynağı açısından ele alarak doğa ve insan nedenli olarak ikiye ayırmaktadır. Geçmişte, 76 yılında İtalya Pompoei'de Vezüv yanardağı patlaması, Japonya'daki 2011 yılında yaşanan ve Fukushima'yı büyük ölçüde etkileyen büyük deprem ve tsunami bunlara örnek gösterilebilir. Günümüzde Pompei ve Japonya Fukushima gözde turizm merkezleri arasında yer almaktadır. İnsan nedenli hüzün turizmi ise insanların isteyerek ya da bilinçsiz bir şekilde neden olduğu, bireyleri ve kitleleri derinden etkileyen olayların yaşandığı mekanları kapsamaktadır ki genellikle hüzün turizminin en büyük kısmını oluşturmaktadır. Tarihte yaşanan büyük savaşlar, Nazilerin toplama kampları, Çernobil nükleer felaketi, Bosna Hersek'te Sırpların gerçekleştirdiği Srebresinita katliamı vb. olayların geçtiği alanlara yapılan ziyaretler insan nedenli hüzün turizmine örnek gösterilebilir. 
Tablo 2. Hüzün Turizminin Sınıflandırılması

\begin{tabular}{|c|c|}
\hline Hüzün turizminin Bölümleri & Kapsamı \\
\hline $\begin{array}{l}\text { Tehlikeli yerler: Geçmişten günümüze } \\
\text { tehlikeli destinasyonlar }\end{array}$ & $\begin{array}{ll}- & \text { Korku şehirleri } \\
- & \text { Tehlikeli destinasyonlar } \\
\end{array}$ \\
\hline $\begin{array}{l}\text { Korku evleri: Gerçek ya da temsili ölüm ve } \\
\text { korku ile bağlantılı yapılar }\end{array}$ & $\begin{array}{l}\text { Ölüm zindanları } \\
-\quad \text { Son derece korkutucu ve mide } \\
\text { bulandırıcı oteller }\end{array}$ \\
\hline $\begin{array}{l}\text { Kötü kaderı alanları: Ölüm, korku, ün veya } \\
\text { kötü şöhret ile anılan alanlar veya yerler }\end{array}$ & $\begin{array}{ll}- & \text { Kanlı savaş alanları } \\
- & \text { Soykırım yapılan alanlar } \\
- & \text { Ünlülerin mezarları } \\
\end{array}$ \\
\hline $\begin{array}{l}\text { İşkence Turları: Ölüm, cinayet ve çaresizliğin } \\
\text { yaşandığı yerlere turlar veya ziyaretler }\end{array}$ & $\begin{array}{l}\text { - Çaresiz, savunmasız bırakma ve } \\
\text { cinayet } \\
-\quad \text { Günümüzde kötü şöhretli olan } \\
\text { yerler }\end{array}$ \\
\hline $\begin{array}{l}\text { Ölüm temalı: Ölüm ve acı çekmeyi yansıtan } \\
\text { eşyalar, müzeler }\end{array}$ & $\begin{array}{ll}- & \text { Ürkütücü müzeler } \\
- & \text { Barış ve erdem antları }\end{array}$ \\
\hline
\end{tabular}

Kaynak: Stone, 2010: 44

Hüzün turizmi bir alternatif turizm olarak hem özel ilgi turizmi kapsamında hem de kültürel miras turizmi altında değerlendirilmekte, bu da ne tür bir sınflandırma içinde yer alacağına dair bazı soru işaretleri oluşturmaktadır. Örneğin bazı çalışmalarda hüzün turizmi miras turizminin bir çeşidi olarak değerlendirilirken (Farmaki, 2013; Hartmann, 2014; K1lıç ve Akyurt, 2011; Niemela, 2010; Trauer, 2006), araştırmaların bazılarında ise özel ilgi turizmi altında ele alınmıştır (Alili, 2017; Bozok vd., 2014, Niemela, 2010; Trauer, 2006; Yıldız vd., 2015). Hüzün turizmi ile özel ilgi turizmi arasındaki ilişki her ikisininin de kitlesel turizmin niteliklerine uzak, bireysel seyehatlere yönelik olmasında yatmaktadır. Özel ilgi turizmi iki önemli göstergeye sahiptir; birincisi boş zaman kapsamında özel ilginin oluşması, ikincisi ise bu boş zamanın ticarileşerek turizm faaliyeti haline dönüşmesidir (Trauer, 2006). Bu bağlamda özel ilgi turizmi kişilerin ilgilerinin yoğunlaştığı alanlarda doyum elde edebilmek amacıyla yaptıkları seyahatler ve ilgili faaliyetler olarak tanımlanmakta (Yıldız vd., 2015), doğal olarak bu faaliyetler tradejik olayların yaşandığı alanlara yapılan ziyaretleri de kapsamaktadır. Bu bağlamda, kültürel mirası da kapsayacak bir şekilde, hüzün turizminin kültürel, tarihsel miras ve eğitsel özellikler/nitelikler taşıyan kompleks bir turizm branşı olduğu, özellikle de niş turizmin bir parçası olarak özel ilgi turizmi altında değerlendirilmesi görüşü ileri sürülmektedir. (Niemela, 2010; Trauer, 2006). Bir diğer ifadeyle, hüzün turizmi tarih, kültürel miras ve yaşanmış tradejilerin çok katlı bileşiminden oluşmaktadır (Varma ve Jain, 2013). Bu noktada hüzün turizmi, özel ilgi ve kültürel miras turizmi ile harmanlaşmış bir kavramı yansıtmaktadır. Hüzün turizmi ile kültürel miras turizm arasındaki temel farklılık hüzün turizminin sık sık bir çeşit vahşet ve gaddarlıkla ilişkilendirilmesinde yatmaktadır (Podoshen, 2013).

Tablo 3. Dünyada ve Türkiye'de En Çok Ziyaret Edilen Seçilmiş Bazı Hüzün Turizmi Alanları

\begin{tabular}{|l|l|l|}
\hline $\begin{array}{l}\text { Alan ya da } \\
\text { Çekim Unsuru }\end{array}$ & Yer & Açıklama \\
\hline $\begin{array}{l}\text { Toplama ve ve } \\
\text { İmha kampı }\end{array}$ & $\begin{array}{l}\text { Auschwitz } \\
\text { (Polonya) }\end{array}$ & $\begin{array}{l}\text { 1941 ve 1945 yılları arasında 1 milyon insan 3 } \\
\text { toplama kampinda toplanmıs, yaklaşı 150 bini } \\
\text { acılar çektirilerek soykırıma uğramıştır. Her yıl } \\
\text { yaklaşık 1,4 milyon insan ziyaret etmektedir. }\end{array}$ \\
\hline
\end{tabular}




\begin{tabular}{|c|c|c|}
\hline $\begin{array}{l}\text { Ground Zero- } \\
\text { Ulusal } 11 \text { Eylül } \\
\text { Anitı }\end{array}$ & $\begin{array}{l}\text { New } \\
\text { (A.B.D) }\end{array}$ & $\begin{array}{l}200111 \text { Eylül'de yaklaşık 3,000 kişi terör saldırısı } \\
\text { nedeni ile hayatını kaybetmiştir. Her yıl yaklaşık } 1 \\
\text { milyon kişi tarafından ziyaret edilmektedir. }\end{array}$ \\
\hline $\begin{array}{l}\text { Hiroshima } \\
\text { Barış Anıt } \\
\text { Parkı }\end{array}$ & $\begin{array}{l}\text { Hiroshima } \\
\text { (Japonya) }\end{array}$ & $\begin{array}{l}1945 \text { yılında atılan atom bombası nedenyiule şehir } \\
\text { tamamen harabeye dönmüş, yüzbinlerce insan } \\
\text { jayatını kaybetmiş ve sakat kalmıştır. Müze, açıldığ1 } \\
\text { tarihten (1955) bugüne kadar } 53 \text { milyon kişi } \\
\text { tarafından ziyaret edilmiştir. }\end{array}$ \\
\hline $\begin{array}{l}\text { Kont Drakula } \\
\text { Şatosu-Dran } \\
\text { Kalesi }\end{array}$ & $\begin{array}{l}\text { Wallachia- } \\
\text { Transylvania } \\
\text { (Romanya) }\end{array}$ & $\begin{array}{l}\text { Yıllık } 500 \text { bin kişi tarafından ziyaret edilmektedir. } \\
\text { Binlerce kişi kazıklara oturtulmak vb. akıl almaz } \\
\text { işkence yöntemleriyle öldürülmüştür. Aynı } \\
\text { zamanda vampir teması da taşımaktadır. }\end{array}$ \\
\hline Pompeii & Naples (İtalya) & $\begin{array}{l}\text { M.Ö } 79 \text { yılında Vezüv yanardağının patlaması ile } \\
\text { tüm şehir kül ve kızgın lavlar altında kalmış, } \\
\text { binlerce kişi taşlaşarak ölmüştür. Yıllık 2,5 milyon } \\
\text { ziyaretçisi bulunmaktadır. }\end{array}$ \\
\hline Leap Kalesi & $\begin{array}{l}\text { Coolderry } \\
\text { County Offaly } \\
\text { (İrlanda) }\end{array}$ & $\begin{array}{l}\text { M.S. } 1500 \text { 'lü yıllarda inşa edilen, perilili ve hayaletli } \\
\text { kale olarak bilinen bu yer yıllık } 800 \text { bin ziyaretçi } \\
\text { çekmektedir. }\end{array}$ \\
\hline Pere-Lachaise & Paris (Fransa) & $\begin{array}{l}\text { Parisin en büyük mezarlığı olup, yıllık } 3,5 \text { milyon } \\
\text { ziyaretçisi ile dünyada en çok ziyaret edilen } \\
\text { mezarlıklıklardan birisidir. }\end{array}$ \\
\hline Alma Bridge & Paris (Fransa) & $\begin{array}{l}1997 \text { yılında Prenses Diana'nın araba kazasında } \\
\text { hayatını kaybettiği tünel. Milyonlarca kişi } \\
\text { tarafından ziyaret edilmektedir. }\end{array}$ \\
\hline $\begin{array}{l}\text { Arlington } \\
\text { National } \\
\text { Cemetery }\end{array}$ & $\begin{array}{l}\text { Virginia } \\
\text { (A.B.D) }\end{array}$ & $\begin{array}{l}\text { Çoğunluğunu Amerikan iç savaşında ölenlerin } \\
\text { oluşturduğu mezarlık, yaklaşık yıllık } 4 \text { milyon } \\
\text { ziyaretçisi bulunmaktadır. }\end{array}$ \\
\hline $\begin{array}{l}\text { Alcatraz } \\
\text { Federal } \\
\text { Hapishanesi }\end{array}$ & $\begin{array}{l}\text { San Franxisko } \\
\text { Körfezi (A.B.D) }\end{array}$ & $\begin{array}{l}\text { Bir zamanların en yüksek güvenliğe sahip, diğer } \\
\text { hapishanelerde sorun çıkaran en tehlikeli } \\
\text { mahkûmların tutulduğu yer olarak bilinen } \\
\text { hapishane sonradan müzeye dönüştürülmüş olup, } \\
\text { yılda 1,5 milyon ziyaretçi çekmektedir. }\end{array}$ \\
\hline $\begin{array}{l}\text { Cernobil } \\
\text { Felaketi }\end{array}$ & $\begin{array}{l}\text { Pripyat } \\
\text { (Ukrayna) }\end{array}$ & $\begin{array}{l}1986 \text { yılında meydana gelen nükleer santral } \\
\text { felaketten sonra kent terkedilmiştir. Bugün yıllık } \\
\text { yaklaşık } 10 \text { bin civarında ziyaretçisi vardır. }\end{array}$ \\
\hline $\begin{array}{lr}\text { Gelibolu } & \text { Adası } \\
\text { Tarihi } & \text { Milli } \\
\text { Park1 } & \end{array}$ & $\begin{array}{l}\text { Çanakkale } \\
\text { (Türkiye) }\end{array}$ & $\begin{array}{l}1973 \text { yılında milli park ilan edilen alanda } 1915-1916 \\
\text { yılları arasında Çanakkale savaşları meydana } \\
\text { gelmiş ve yaklaşık yarısı Türk, yarısı yabancı } 500 \\
\text { bin asker hayatını kaybetmiştir. Alan } 2018 \text { yılında } \\
\text { 2,5 milyon kişi tarafından ziyaret edilmiştir. }\end{array}$ \\
\hline Anitkabir & $\begin{array}{l}\text { Ankara } \\
\text { (Türkiye) }\end{array}$ & $\begin{array}{l}\text { Türkiye Cumhuriyeti'nin kurucusu M. Kemal } \\
\text { Atatürk'ün anıt mezarının bulunduğu alanı } 2018 \\
\text { yılında yaklaşık 6,58 milyon kişi ziyaret etmiş olup, } \\
\text { bunun } 280 \text { bini yabancıdır. Yaklaşık } 750 \text { bin m² } \\
\text { alana kurulu Anıtkabir'in } 120 \text { bin m² si Anıt Blok, } \\
\text { geri kalanı Barış Parkı'dır. }\end{array}$ \\
\hline
\end{tabular}


Kaynak: (Fonseca vd., 2016; http://www.anitkabir.tsk.tr). Not: Tabloda yer alan yerlerle ilgili gerek kendi internet sitelerinden gerekse ilgili diğer internet sitelerinden ayrıca yararlanılarak bilgi ilavesi yapılmıştır).

Raine (2013), Stone tarafından 2006 yılında yapılan bir çalışmayı biraz daha genişleterek hüzün turizmine katılanların tipolojisini yansıtan bir yelpaze oluşturmuştur. Şekil 1'de de görüldüğü üzere hüzün turizmine katılanlar kendini adamış, deneyimci, keşifçi ve tesadüfi olarak dört gruba ayrılmakta ve hissedilen duyguların şiddeti kendini adamış ziyaretçide en üst seviyede iken, tesadüfi ziyaretçiye doğru en alt seviyeye inmektedir. Bu durum hüzün turizmine yönelik arz ve talep yapısını da doğal olarak etkilemektedir.

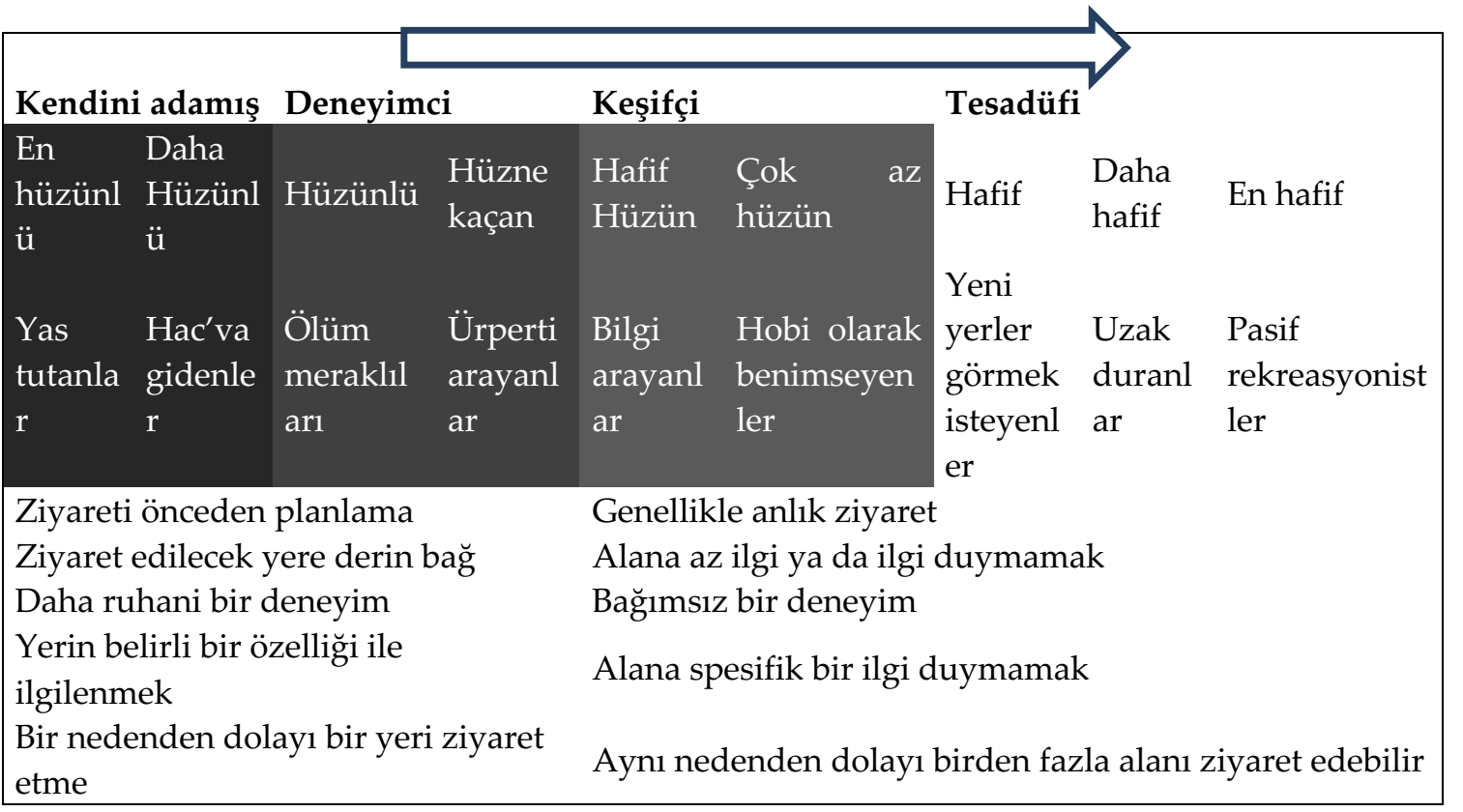

Şekil.1 Mezarlıkları Ziyaret Eden Turistlerin Tipolojisi. En Hüzünlüden-En Hafif Hüzne Doğru (Kaynak: Raine, 2013: 242-256.)

Türkiye'de yapılan bir çalışmada Gelibolu tarihi Milli Parkına yapılan ziyaretler en hüzün verici, Sarıkamış olayları daha hüzünlü olarak ifade dilirken, sinop cevazevi hafif, Anıtkabir ziyaretleri de daha hafif bir hüzün olarak nitelendirilmiştir. Bunda Anıtkabir'e yapılan ziyaretlerin hüzünle (10 Kasım Atatürk'ün ölüm yıldönümünü anma günü) birlikte gurur duyma ve kutlama duygularının da (23 Nisan, 30 Ağustos ve 29 Ekim gibi önemli milli bayramlar) birlikte olması da önemli bir etkendir (Çelik, 2017).

\section{Ulucanlar Cezaevi Müzesi}

1925 yılında inşa edilen Ulucanlar Cezaevinin ilk adı Cebeci Tevfikhanesidir. Sonrasında Cebeci Umumi Hapishanesi, Ankara Hapishanesi, Ankara Cebeci Sivil Cezaevi, Ankara Merkez Kapalı Cezaevi ve sonunda Ulucanlar Cezaevi olarak isimleri değişmiştir. Hapishane açllıktan bir yıl sonra infazların gerçekleştirildiği bir yer haline gelir. 2006 yılına kadar 81 yıl boyunca açık kalan hapishane, farklı siyasi görüşlerden birçok ünlü ismi ağırlamıştır. Nazım Hikmet Ran, Cevat Şakir Kabaağaçlı (Halikarnas Balıkçısı), Necip Fazıl Kısakürek, Deniz Gezmiş, Fakir Baykurt, Yılmaz Güney, Bülent Ecevit ve Muhsin Yazıcıoğlu gibi Türkiye siyasi tarihi açısından ünlü isimlere ev sahipliği yapmıştır. Altındağ Belediyesi tarafından 1925 yılında ilk açldığ zamandaki durumuna uygun bir şekilde restore edilerek müzeye dönüştürülen mekanda mahkumların balmumu heykellerinden, günlük hayatta kullandığı eşyalara kadar tüm ayrıntılar aslına uygun şekilde sergilenmektedir. Burada kalmış olan tanınmış mahkumlar ise 
fotoğraf, belge ve eşyaları ile müzede yer almaktadır (http://www.ulucanlarcezaevimuzesi.com).

Ulucanlar Cezaevi müzesi yıl boyunca açık olan daha çok yerli turistler tarafından ziyaret edilen bir müzedir. Ziyaretler daha çok hafta sonunda gerçekleştirilmektedir. Müze ziyaretleri esnasında görsel ve işitsel rehberlik materyalleri, müze duvarlarında yer alan görseller, eski zamanlarda anı yaşamak adına yer alan fon müziği gelen misafirlere o anları yaşatmaya devam edecek şekilde tasarlanmıştır. Grup ziyaretlerinin yanı sıra hafta sonu aile ziyaretleri de görülmektedir. Gruplar için saatlik randevu sistemi uygulanmaktadır. Müze ile ilgili ayrıntılı bilgi sahibi olunması noktasında bir web sayfası bulunmaktadır. Ziyaretler kırk dakika ile bir saat arasında değişmektedir. Hukuk fakültesi öğrenciler her yıl davet edilen grup olarak dikkati çekmektedir (Kurnaz vd, 2017:199).

\section{YÖNTEM}

Çalışma, güncel bir olayın derinlemesine değerlendirilmesini kapsayan bir yaklaşım olan nitel araştırma desenlerinden olan durum çalışması olarak desenlenmiştir. Durum çalışması, tek bir durum ya da olayın derinlemesine incelendiği, verilerin sistematik bir şekilde toplandığı ve gerçek ortamda neler olduğuna bakıldığı bir yöntemdir. Çoklu durum çalışması ise birden fazla durumun çalışıldığı araştırmalardır (Subaşı ve Okumuş, 2017: 420-422).

$\mathrm{Bu}$ araştırmanın amacı Ankara'da yer alan tarihi Ulucanlar Cezaevi Müzesi ile ilgili tripadvisor.com internet sitesinde yer alan, müzeyi ziyaret eden ziyaretçilerin yorumlarını çözümleyerek, ziyaretçilerin hissettikleri duygu türlerini, memnuniyet düzeylerini ve tavsiyelerini tespit etmektir. Araştırmanın evrenini müzeyi ziyaret eden ziyaretçiler, örneklemini Eylül 2013-Temmuz 2019 tarihleri arasında müzeyi ziyaret eden ve tripadvisor.com adresine ziyareti ile alakalı yorum yazan 317 turist oluşturmaktadır. Araştırmada örnekleme yöntemi olarak, amaçlı örnekleme metotlarından ölçüt örnekleme kullanılmıştır. Örneklemin özelliği problemle ilgili olarak belirlenen niteliklere sahip kişiler, olaylar, nesneler ya da durumlardan oluşturulmasıdır (Büyüköztürk, 2012:11). Ölçüt örneklemdeki asıl nokta seçilecek olan durumun bilgi vermek açısından zengin olmasıdır (Tuncer ve Aksoy, 2017:179). Veriler, doküman incelemesi yoluyla toplanmıştır.

Araştırmanın verileri popüler bir seyahat sitesi olan TripAdvisor.com'dan alınmıştır. Öncelikle Eylül 2013'ten Temmuz 2019 kadar www.tripadvisor.com linkinde yer alan tüm yorumlar word ortamına aktarılmış, kelimelerde yapılmış olan imla ve yazım hataları düzeltilmiş, Türkçe'den farklı dillerde yapılmış olan yorumlar Türkçeye çevrilmiştir. Daha sonra 317 yorum nitel araştırma yöntemlerinden olan içerik analizine tabi tutulmuştur. Bu yöntemde materyalin belirli motiflerinin ne sıklıkta olduğu (metindeki satırlar, değerler, benzer konular vb.) çözümlemenin temelini oluşturmakta, çözümleme birimi kelimeler olabileceği gibi; semboller, boyutlar veya renkler gibi görsel unsurlardan da yararlanılabilmektedir (Erdem ve Gezen, 2014:24; Köroğlu vd, 2017: 34). Araştırma kapsamında verileri analiz etmede MAXQDA 18 programından yararlanılmıştır. İnceleme sonuçlarına göre ortaya çıkan bazı cümle ve paragraflar genel bir çerçeve içinde ortak özelliklere ayrılarak kodlanmış ve kavramsallaştırılmıştır.

Yıldırım ve Şimşek $(2013,290)$, geçerlik kavramının, nitel araştırmalarda elde edilen veriler ve bu verilerden ulaşılan sonuçların çeşitleme, katılımcı ve meslektaş teyidi gibi yöntemler kullanılarak doğrulanması anlamında kullanıldığını belirtmektedir. Araştırmada toplam 795 kodlamanın yapıldığı belirlenmiştir. Araştırmanın güvenirliğini belirlemek amacıyla ziyaretçi yorumlarına ilişkin yapılan kodlamalar bir turizm alan uzmanı akademisyen tarafından da incelenerek "Görüş Birliği" ve "Görüş Ayrllı̆̆ı" olan kodlar belirlenmiştir. Bu iki form 
uzlaşmacılar arası güvenirlilik testlerinden biri olan Kappa testine tabi tutulmuştur. Puanlayıcılar arası güvenirlik belirlemede sıklıkla kullanılan Kappa istatistiği, Cohen (1960) tarafından önerilmiştir. Sınıflama düzeyinde puanlama yapan iki puanlayıcı arasındaki uyumun derecesini belirlemek için geliştirilmiştir (Cohen, 1960). Kappa istatistiği 0 ile 1 arası değer almaktadır. Şencan (2005) tarafından 0.40 değeri ile 0.75 değeri arasında hesaplanan değerin makul bir değer olduğu ve uyuşmanın sağlandığı belirtilmiştir. MAXQDA 2018 nitel veri analiz programı ile yapılan Kappa analizi sonucunda, Kappa Güvenirlik Katsayısı (KGK) değeri 0.77 çıkmıştır. Şencan'a göre, bu değer yeterlilik açısından güvenilirdir.

Araştırma kapsamında verileri analiz etmede profesyonel bir bilgisayar destekli nitel veri analizi programı (computer assisted qualitative data analysis software / CAQDAS) olan lisanslı MAXQDA 18 ile analiz edilmiştir. MAXQDA, 1989 yılından beri araştırmacılar tarafından kullanılmakta olup halen nitel araştırmaların doğasına en uygun hale getirilmek için üzerinde çalışılmaya devam edilen önemli ve güncel bir yazılımdır. Program sayesinde analiz süreci daha açık ve sistematik olarak yapılmış olup, yapılan kodlamaları kontrol ederek gerektiğinde düzenlemeler yapma imkânı elde edilmiştir. İnceleme sorularına göre ortaya çıkan bazı cümle ve paragraflar genel bir çerçeve içinde ortak özelliklere ayrılarak kodlanmış ve kavramsallaştırılmıştır. Daha sonra elde edilen veriler tematik kodlamaya göre düzenlenmiş ve tanımlanmıştır.

\section{BULGULAR}

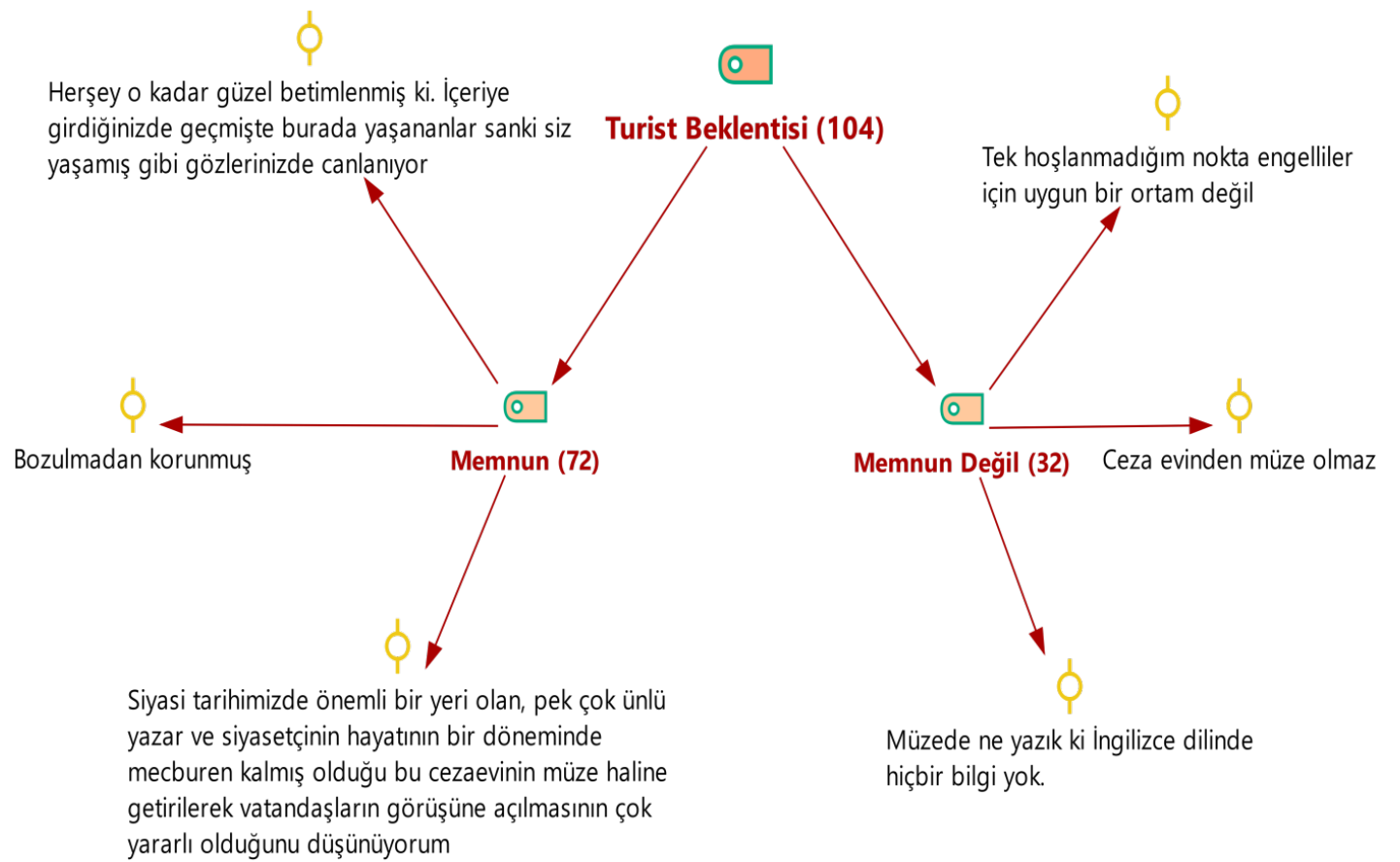

Şekil 2: Ziyaretçilerin Ulucanlar Cezaevi Müzesine Yönelik Memnuniyet Durumlarının Kodlu Bölüm Sayısına Göre Sınıflandırması- Kod-Alt kod Modeli

Şekil 2'de müzeyi ziyaret eden kullanıcıların, yaptıkları ziyaretten ve bölgeden memnun kalıp kalmadıklarına yönelik yaptıkları yorumlardan bazılarına yer verilmiştir. Şekil incelendiğinde müze ziyaretinden memnun kalan ziyaretçi sayısının, memnun kalmayan ziyaretçi sayısından daha fazla olduğu görülmektedir. Yapılan yorumlardan 72 tanesi gerçekleştirilen ziyaretten ve bölgeden memnun kalındığına dair, 32 tanesi ise memnun kalınmadığına dair yapılan yorumlardır. Müzenin beğenilen kısmının içerideki eşyaların bozulmadan korunmuş olması, 
içeride yapılan betimlemelerin çok iyi durumda olması ve o zamanlar mahkumların yaşadıklarının etkili bir şekilde canlandırılması olduğu görülmektedir. Müzeyle ilgili beğeni içeren yorumlara örnek verilecek olunursa," her şey o kadar güzel betimlenmiş ki içeriye girdiğinizde geçmişte burada yaşananlar sanki siz yaşamış gibi gözlerinizde canlanıyor; siyasi tarihimizde önemli bir yeri, pek çok ünlü yazar ve siyasetçinin hayatının bir döneminde meeburen kalmış olduğu bu cezaevinin müze haline getirilerek vatandaşların görüşüne açılmasının çok yararlı olduğunu düşünüyorum vb. yorumlardır. Ziyaretçilerin müze ziyaretinden memnun almadığını belli eden yorumlara bakıldığında "cezaevinden müze olmaz, müzede ne yazıkki İngilizce dilinde hiçbir bilgi yok vb" yorumlardir.

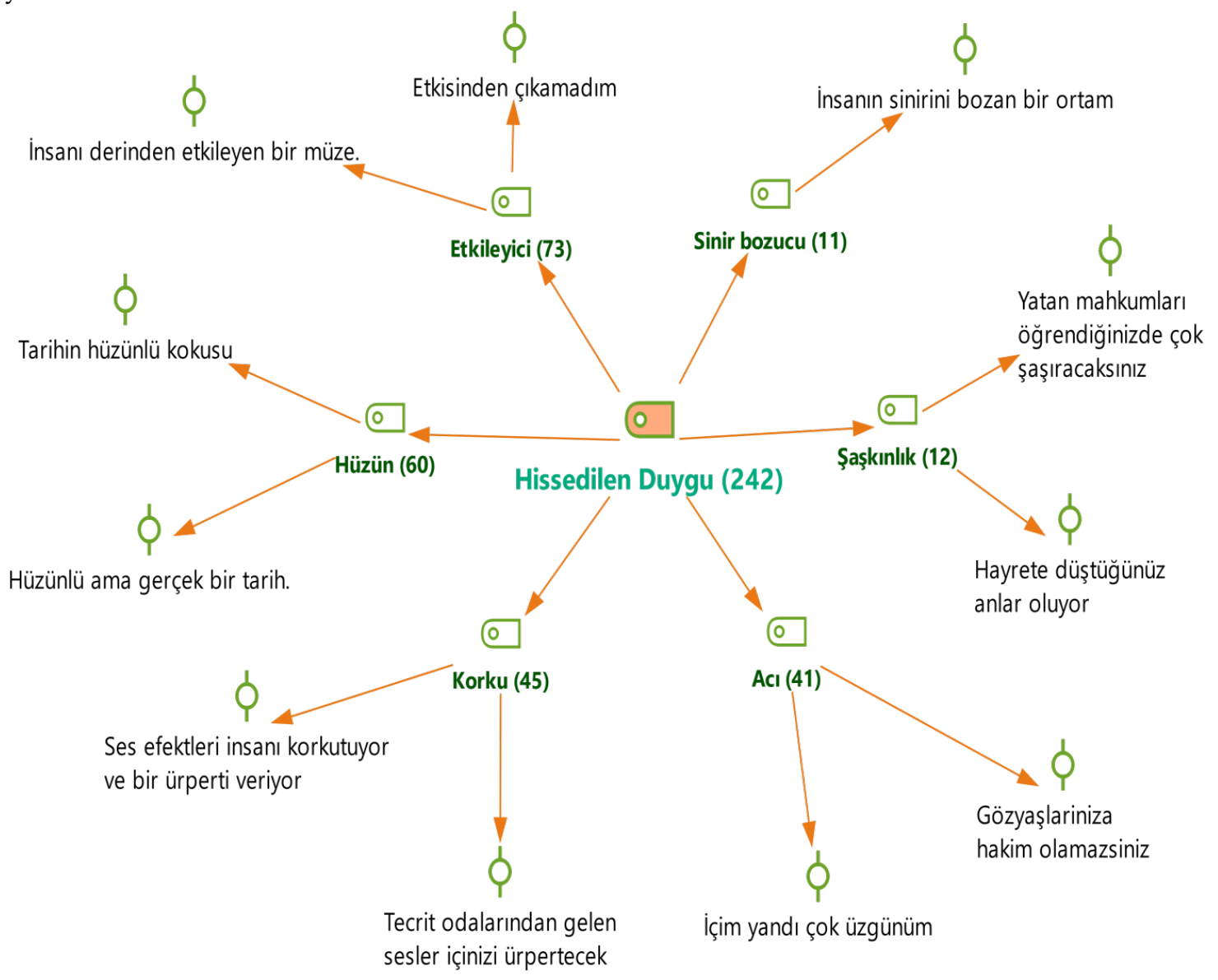

Şekil 3: Ziyaretçilerin Ulucanlar Cezaevi Müzesi Ziyaretleri Sonrasında Hissettikleri duyguları İfade Eden Yorumların Kodlu Bölüm Sayısına Göre Sınıflandırması- Kod-Alt kod Modeli

Şekil 3'te Ulucanlar Cezaevi Müzesini ziyaret eden ziyaretçilerin ziyaretleri sonrasında hissettiklerini ifade eden yorumların kodlanmış halleri verilmiştir. Şekle göre, katılımcıların ziyaret sonrası hissettikleri duyguları belirten 242 yorum tespit edilmiştir. Bu yorumların "korku, hüzün, etkileyici, acı, sinir bozucu ve şaşkınlık duygu temalı 6 alt kategoride oldukları görülmektedir. En çok yorumun "etkileyici" ve "hüzün" alt temalı yorumlar olduğu görülmektedir. En az yorum ise "sinir bozucu" ve "şaşkınlık" alt temalı yorumlardır. Yorumlara örnekler verilecek olursa, "etkileyici" alt temada "insan derinden etkileyen bir müze; etkisinden çıkamadım", 'hüzün' alt temada "tarihin hüzünlü kokusu;hüzünlü ama gerçek bir tarih", ' korku" alt temada "ses efektleri insan korkutuyor ve bir ürperti veriyor", tecrit odalarından gelen sesler içinizi ürpertecek", 'acı' alt temada "içim yandı çok üzgünüm, göz yaşlarınıza hakim olamayacaksınız",' şaşkınlık' alt temada "yatan mahkumları öğrendiğinizde çok şaşıracaksınız, hayrete düştüğ̈̈nüz anlar oluyor, 'sinir bozucu ' alt temada ise insanin sinirini bozan bir ortam vb. yorumlardır. 2. ve 3. Şekil 
birlikyte incelendiğinde Ulucanlar Cezaevi Müzesi'nin önemli bir hüzül turizm potansiyeline sahip olduğu söylenebilir.

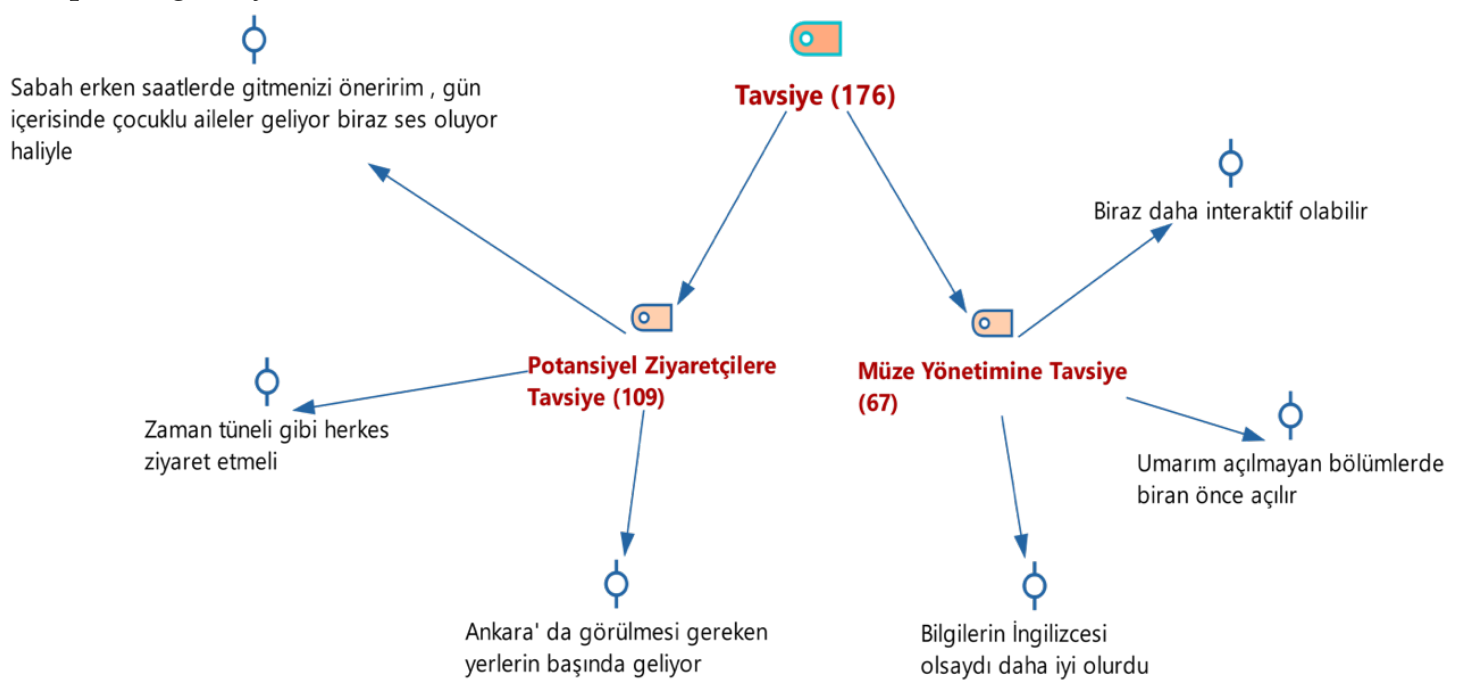

Şekil 4: Ziyaretçilerin Ulucanlar Cezaevi Müzesi ile İlgili Tavsiyelerinin Kodlu Bölüm Sayısına Göre Sinıflandırması Kod-Alt kod Modeli

Şekil 4'te de görüldüğü gibi yorumcular 176 ifade ile Ulucanlar Cezaevi Müzesi ile ilgili hem müzeyi ziyaret edecek potansiyel ziyaretçilere hem de müze yönetimine tavsiyede bulunmaktadırlar. Yazılan tavsiye içerikli yorumların çoğunluğunun potansiyel ziyaretçilere yönelik yorumlar olduğu görülmektedir. Bu yorumların bazılarına bakıldığında " zaman tüneli gibi herkes ziyaret etmeli, sabah erken saatlerde gitmenizi öneririm, gün içerisinde çocuklu aileler geliyor, biraz ses oluyor haliyle, Ankara'da görülmesi gereken yerlerin başında geliyor" vb yorumlardır. Müze yönetimine yönelik ziyaretçilerin yazdıkları yorumlarda " biraz daha interaktif olabilir, umarım açılmayan bölümler bir an önce açılır, bilgilerin Ingilizcesi olsaydı daha iyi olurdu" vb yorumlardır.

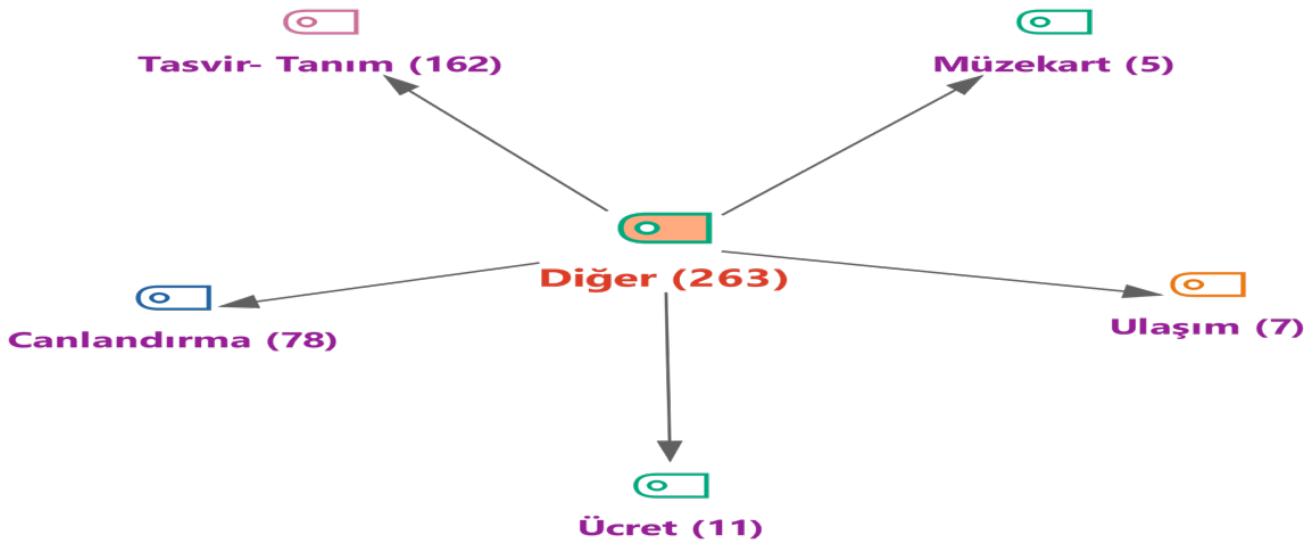

Şekil 5: Ziyaretçilerin Ulucanlar Cezaevi Müzesi ile Yaptıkları Diğer Yorumların Kodlu Bölüm Sayısına Göre Dağılımları Kod-alt Kod Modeli

Şekil 5'te Ziyaretçilerin müzeyle ilgili yaptıkları diğer yorumların kodlandığı alt temalar verilmiştir. Ziyaretçiler son olarak Ulucanlar Cezaevi Müzesini ve içerisinde bulunan eserleri tasvir eden ve tanıtan 162 yorum, müze içerisindeki balmumu heykeller ve ses efektleri ile yapılan canlandırmaları anlatan 78 yorum, müze giriş ücreti ile ilgili 11 yorum, müzekartla girişle ilgili 5 yorum ve müzeye farklı ulaşım araçlarıyla gerçekleştirilebilecek ulaşımla ilgili 7 yorum yazmışlardır. 


\section{SONUÇ VE TARTIŞMA}

Yakın tarihinde yaşanılan sıkıntılı, hüzünlü, üzüntü verici olaylar sebebiyle önemli bir hüzün turizm potansiyeli olan Türkiye'de yeni bir hüzün turizmi destinasyonu da başkent Ankara'da yer alan, Cumhuriyetin ilk hapishanelerinden biri, şimdilerde müze olarak faaliyetlerini devam ettiren Ulucanlar Cezaevi Müzesi'dir. 81 yıllık faaliyet süresi içinde, yakın Türk siyasi tarihine adı geçen farklı görüşlerdeki aydınların, devlet adamlarının ve siyasilerin yattığı, insanı hüzne boğan işkence, idam gibi olayların yaşandığı Ulucanlar Cezaevi günümüzde birçok insanın merakla ziyaret etttiği, hüzün turimine kapılarını açan bir müze haline gelmiştir. Tarihte yaşanılan, savaş, açlık, doğal felaketler vb kötü olayların yaşandığı alanlara yönelik gerçekleştirilen hüzün turizmine hizmet veren bir ziyaret yeri olan Ulucanlar Cezaevi Müzesinin varlığını devam ettirmesi, orayı ziyaret eden ziyaretçilerin sürdürülebilirliği ile alakalıdır. Bu konuda söz konusu müzeyi ziyaret eden ziyaretçilerin ziyaretleri sonrasında hissettikleri duygular, görüşler, eleştiriler, tavsiyeler, memnuniyet veya memnuniyetsizlik durumlarının tespiti önem arz etmektedir. Bu çalışmada tüm bu sayılan unsurların tespit edilmesi amaçlanmıştır. Bu amaçla dünyada en çok kullanılan sosyal paylaşım platformlarından biri olan tripadvisor.com adlı internet sitesinde, Ulıucanlar Cezaevi Müzesi ile ilgili Eylül 2013-Temmuz 2019 arasında yazılan 317 yorum içerik analizine tabi tutulmuştur. Nitel bir veri analizi paket programı kullanılan araştırmada toplamda müzeyle ilgili 317 yoruma yapılan içerik analizde yorumlar, "turist beklentisi", "hissedilen duygu", "tavsiye," ve "diğer" yorumlar olmak 4 temel tema altında gruplandırılmış ve kodlanmıştır.

Analiz sonucunda ortaya çıkan sonuçlardan en dikkat çekicilerine bakıldığında, ziyaretçilerin çoğunluğunun müzeyi beğendiği ve ziyaretten memnun kaldığı, çoğunlukla müzeyi sonradan ziyaret edecek potansiyel ziyaretçilere mutlaka görülmesi gerektiği yönünde, müze yönetimine alanda fiziksel imkanların artırılması yönünde yorumlardır. Ziyaretçilerin ziyaret sonrası hissettikleri dugu ise çoğunlukta etkileyici, hüzün ve korku ağırlıklı duygular olduğu görülmektedir. Bütün bu bulgular değerlendirildiğine Ulucanlar Cezaevi Müzesinin önemli bir hüzün turizmi potansiyeline sahip olduğu söylenebilir.

Türkiye'de hüzün turizmi kapsamında değerlendirilen cezaevleri ile ilgili çalışmalara bakıldığında bu çalışmayla paralel sonuçlara ulaşıldığı görülmektedir. Örneğin, Aslan (2015) hüzün turizminin bir türü olan cezaevi turizmi üzerine bir çalışma yapmıştır. Çalışmada Türkiye tarihinde cezaevlerinin ve savaş alanlarının önemli olduğu ve Sinop Cezaevi'nin yapısı ve tarihi önemi belirtilmiştir. Ayrıca müzeye çevrilen cezaevlerinin turistler için ilgi çekici olduğu saptanmıştır. Belli ve Özdemir (2018) tarafından yapılan bir başka çalışmada, Sinop Cezaevi hüzün turizmi açısından tripadvisor yorumları incelenmiş ve elde edilen sonuca göre, yorumlarda en göze çarpan ifadelerin "kesinlikle görülmesi gereken bir destinasyon", "oldukça etkileyici bir mekan" vb ifadeleri içerdiği görülmüştür. Bir başka çalışmada Kurnaz vd (2017) yine Ulucanlar Cezaevi Müzesini işlemişler. Örnek olay yöntemi kullanarak yaptıkları araştırmada, yarı yapılandırılmış mülakatlarla elde ettikleri verilere dayalı olarak, cezaevini çok sayıda insanın ziyaret ettiği, gelen insanların cezaevinden ve içerisinde bulunan eserlerden çok etkilendiği, hüzünlendiği, göz yaşı döktükleri ortaya çıkmıştır. Çetinsöz (2017)'ün Ulucanlar Cezaevi Müzesi'ne yönelik olarak yaptığı araştırmada, 127 elektronik yorumu analiz ederek sınıflandırmış ve 6 boyut belirlemiştir, çalışmada müzeyi ziyaret eden ziyaretçilerin müzeden etkilendikleri sonucu ortaya çıkmışır. Tüm bu çalışmalara bakıldığında müzenin önemli bir hüzün turizmi potansiyeline sahip olduğu bu çalışmayla bir kez daha teyit edilmiş olmaktadır.

Araştırma bulguları doğrultusunda, müze yönetimine şu önerilerde bulunulabilinir; 
- Müzenin geçmişiyle ilgili, eski fotoğraflar ve orada kalanlarla ilgili bilgileri de içeren 10-15 dakikalık bir tanıtım belgeseli veya kısa film hazırlanıp, ziyaret öncesinde ziyaretçilere söz konusu kısa film izletilip, ziyaretçilerin müzeyle alakalı bilgi sahibi olmaları ve dolu dolu bir ziyaret deneyimine sahip olmaları sağlanabilir.

- Müzenin ziyarete açık olmayan diğer tüm bölümleri de gerekli restorasyondan geçtikten sonra ziyarete açlabilir.

- Müzeyi ziyaret eden yabancı turistler için eserlerin, canlandırmaların ve hapishane bölümerinin yakınlarına İngilizce tanıtım etiketleri koyulabilir.

\section{KAYNAKÇA}

Alaeddinoğlu, F., ve Aliağaoğlu, A. (2007). Savaş Alanları Turizmine Tipik Bir Örnek: Büyük Taarruz ve Başkomutan Tarihi Milli Parkı. Anatolia: Turizm Araştırmaları Dergisi, 18(2), 215-225.

Aliağaoğlu, A. (2004). Sosyo-kültürel miras turizmi ve Türkiye'den örnekler. Coğrafi Bilimler Dergisi, 2(2), 50-64.

Alili, M. (2017). Avrupa'daki ve Türkiye'deki Hüzün Turizmi Destinasyonlarının Karşılaştırılması Üzerine Teorik Bir Çalışma. Uluslararası Global Turizm Araştırmaları Dergisi, $1(1), 37-50$.

Aslan, S. (2015). Prison Tourism as a Form of Dark Tourism, Uluslararası Sosyal Araştırmalar Dergisi, 8(40), 600-608.

Atay, L. ve Yeşildağ, B. (2010). Savaş alanları ve turizmi, Aksaray Üniversitesi İ̈BF Dergisi, 2(2): 65-72

Belli, S. ve Özdemir, E. G. (2018). Sinop Cezaevi'nin Hüzün Turizmi Çerçevesinde İncelenmesi: TripAdvisor Örneği. 1st International Congress of New Generatıon and New Trends in Tourlsm (0103 November 2018) Sapanca Turkey.

Birdir, K., Dalgıç, A., Güler, O., ve Kayaalp, Y. (2015). Hüzün turizmi: Gelibolu Yarımadası Tarihi Milli Parkını ziyaret eden yabancı turistlerin deneyimleri. Journal of Tourism and Gastronomy Studies, 3(4): 12-23

Bowman, M. S., and Pezzullo, P. C. (2009). What's so 'dark'about 'dark tourism'?: Death, tours, and performance. Tourist Studies, 9(3), 187-202.

Bozok, D., Açıksözlü, Ö., Şahin, N. N., ve Varol, İ. (2014). Turistlerin Kişilik Özellikleri ile Postmodern Turizme Eğilimleri Arasındaki İlişkiyi İncelemeye Yönelik Bir Araştırma, Balıkesir İli Örneği. In 9th Internatıonal Conference: New Perspectıves In Tourısm And Hospitality (pp. 849871).

Büyüköztürk, Ş. (2012). Örnekleme Yöntemleri, http://w3.balikesir.edu.tr/ msackes/wp/wpcontent/uploads/2012/03/BAY-Final-Konulari.pdf, Erişim tarihi: 15.11.2019.

Cohen, J. (1960). A Coefficient Of Agreement For Nominal Scales. Educational and Psychological Measurement, 20 (1), 37-46.

Çelik, A. (2017). Hüzün Turizmi Üzerine Bir Derleme. Türk Turizm Araştırmaları Dergisi, 1(3), 4155.

Çetinsöz, B. C. (2017). Karanlık Dark Alanları Ziyaret Eden Yerli Turistleri Motive Eden Etmenler Ankara Ulucanlar Cezaevi Müzesine Yönelik Bir İçerik Analizi. 2. Uluslararası Sosyal Bilimler Sempozyumu, Alanya. 
Dann, G. M., and Seaton, A. V. (2013). Slavery, contested heritage, and thanatourism. Routledge: Abingdon/UK.

Doğaner, S. (2006). Savaş ve turizm: Troya ve Gelibolu savaş alanları. Türk Coğrafya Dergisi, (46), $1-21$.

Dunkley, R. A. (2007). The thanatourist: Collected tales of the thanatourism experience (Doctoral dissertation, University of Wales).

Erdem, B. ve Gezen, T., (2014). Turizm İşletmelerine Yönelik İş İlanlarının İçerik Analizi Yöntemiyle İncelenmesi, Uluslararası Yönetim İktisat ve İşletme Dergisi, 10 (21): 19-42.

Farmaki, A. (2013). Dark tourism revisited: a supply/demand conceptualisation. International Journal Of Culture, Tourism And Hospitality Research, 7(3), 281-292.

Foley, M., and Lennon, J. J. (1996). JFK and dark tourism: A fascination with assassination. International Journal of Heritage Studies, 2(4), 198-211.

Fonseca, A.P., Seabra, C. and Silva, C. (2016) Dark Tourism: Concepts, Typologies and Sites. Journal of Tourism Research and Hospitality, Special issue:1-6.

Friedrich, M., and Johnston, T. (2013). Beauty versus tragedy: thanatourism and the memorialisation of the 1994 Rwandan Genocide. Journal of Tourism and Cultural Change, 11(4), 302-320.

Hartmann, R. (2014). Dark tourism, thanatourism, and dissonance in heritage tourism management: New directions in contemporary tourism research. Journal of Heritage Tourism, 9(2), 166-182.

Holguin, S. (2005). National Spain Invites You: Battlefield Tourism during the Spanish Civil War. The American Historical Review, 110(5), 1399-1426.

http://www.anitkabir.tsk.tr/05_etkinlikler_duyurular/anitkabir_ziyaretci_sayilari.html

https://catab.ktb.gov.tr/Eklenti/53608,canakkale-destani-tanitim-merkezi-verileripdf.pdf?0

https://www.ulucanlarcezaevimuzesi.com/default.asp?page=icerik\&id=27

http://www.ulucanlarcezaevimuzesi.com. Erişim Tarihi:20.08.2018

Ilgar, R. (2015). Mabetleşen bir mekân: Gelibolu Yarımadası tarihi savaş alanları turizmi, Çanakkale Araştırmaları Türk Yıllı̆̆̆, 13(19):1-20

Kavraz, M. (2018). Colosseum. International Journal of Social And Humanities Sciences, 2(1), 11-22.

Kılıç, B., ve Akyurt, H. (2011). Destinasyon İmajı Oluşturmada Hüzün Turizmi: Afyonkarahisar ve Başkomutan Tarihi Milli Parkı. Gaziantep University Journal of Social Sciences, 10(1), 209-232.

Kılıç, B., ve Sop, S. A. (2011). Hüzün turizmi, katarsis ve alternatif katarsistik bir destinasyon örneği olarak San Jose Madeni. Seyahat ve Otel İşletmeciliği Dergisi, 8(3).

Knudsen T, B. (2011). Thanatourism: Witnessing difficult pasts. Tourist Studies, 11(1), 55-72.

Köroğlu, Ö., Dumanlı, Ş., Şalk, S., İnanır, İ., Gürsoy, H. Karataş Bahar, A.ve Özgöller. G. (2017). Müzelere Yönelik Olumsuz Kullanıcı Güdümlü İçerik Çözümlemesi: TripAdvisor.Com Örneği. Journal of Recreation and Tourism Research, 4 (3): 29-48

Kuo, N. T., Chang, K. C., Cheng, Y. S., and Lin, J. C. (2016). Effects of tour guide interpretation and tourist satisfaction on destination loyalty in Taiwan's Kinmen Battlefield Tourism: 
perceived playfulness and perceived flow as moderators. Journal of Travel \& Tourism Marketing, 33(sup1), 103-122.

Kurnaz, H. A., Çeken, H., ve Kılıç, B. (2013). Hüzün turizmi katılımcılarının seyahat motivasyonlarının belirlenmesi. İsletme Araştırmaları Dergisi, 5(2), 57-73.

Kurnaz, H. A., Kurnaz, A. ve Tatlığlu, C. (2017). Hüzün Turizmi Destinasyonlarına Bir Örnek: Ulucanlar Cezaevi, Eurasian Academy of Sciences Social Science Journal: UKTM Özel Sayısl: 193-200

Lee, C. K., Bendle, L. J., Yoon, Y. S., and Kim, M. J. (2012). Thanatourism or peace tourism: Perceived value at a North Korean resort from an indigenous perspective. International Journal of Tourism Research, 14(1): 71-90.

Lennon, J. J., and Foley, M. (2000). Dark tourism. Cengage Learning EMEA.

Lewis, C. (2008). Deconstructing Grief Tourism. International Journal of the Humanities, 6(6):165169

Light, D. (2017). Progress in dark tourism and thanatourism research: An uneasy relationship with heritage tourism. Tourism Management, 61, 275-301.

Lloyd, D. W. (2014). Battlefield tourism: Pilgrimage and the commemoration of the Great War in Britain, Australia and Canada, 1919-1939. A\&C Black.

Miles, W. F. (2002). Auschwitz: Museum interpretation and darker tourism. Annals of Tourism Research, 29(4), 1175-1178.

Miles, S. (2014). Battlefield sites as dark tourism attractions: An analysis of experience. Journal of Heritage Tourism, 9(2), 134-147.

Niemela, T. (2010). Motivation factors in dark tourism: Case House of Terror at Lahti. Nature and Soft Adventure Tourism.

Okuyucu, A., ve Erol, F. (2018). Savaş Alanları Turizmine Yönelik Motivasyon, Duygu ve Deneyimler: Metristepe ve İnönü Şehitlikleri-Bozüyük Örneği. Coğrafi Bilimler Dergisi, 16(1), 135-151.

Podoshen, J. S. (2013). Dark tourism motivations: Simulation, emotional contagion and topographic comparison. Tourism Management, 35, 263-271.

Raine, R. (2013). A dark tourist spectrum. International Journal of Culture, Tourism And Hospitality Research, 7(3), 242-256.

Seaton, A. V. (1996). Guided by the dark: From thanatopsis to thanatourism. International Journal of Heritage Studies, 2(4), 234-244.

Seaton, A. V. (1999). War and thanatourism: Waterloo 1815-1914. Annals of Tourism Research, 26(1), 130-158.

Slade, P. (2003). Gallipoli thanatourism: The meaning of ANZAC. Annals of Tourism Research, 30(4), 779-794.

Slayton, L. S. (2006). Ground Zero-Tragedy, Terror, and Grief Tourism. Mart, 6, 2016.

Stone, P. (2013). Dark tourism scholarship: A critical review. International Journal of Culture, Tourism and Hospitality Research, 7(3), 307-318.

Stone, P. R. (2006). A dark tourism spectrum: Towards a typology of death and macabre related tourist sites, attractions and exhibitions. Turizam: međunarodni znanstveno-stručni časopis, 54(2), $145-160$. 
Stone, P. R. (2010). Death, dying and dark tourism in contemporary society: A theoretical and empirical analysis (Doctoral dissertation, University of Central Lancashire).

Stone, P. R. (2012). Dark tourism and significant other death: Towards a model of mortality mediation. Annals of Tourism Research, 39(3), 1565-1587.

Stone, P., and Sharpley, R. (2008). Consuming dark tourism: A thanatological perspective. Annals of Tourism Research, 35(2), 574-595.

Strange, C., and Kampa, M. (2003). Shades of dark tourism: Alcatraz and Robben Island. Annals of Tourism Research, 30(2), 386-405.

Subaşı, M. ve Okumuş, K. (2017). Bir Araştırma Yöntemi Olarak Durum Çalışması, Atatürk Üniversitesi Sosyal Bilimler Enstitüsü Dergisi, 21 (2), 419-426.

Şencan, H. (2005). Sosyal ve Davranışsal Ölçümlerde Güvenirlik ve Geçerlilik. Ankara: Seçkin Yayıncilik.

Tarlow, P. (2007). Dark tourism-the appealing 'dark'side of tourism and more. in Niche tourism (pp. 61-72). Routledge.

Tonner, S. L. (2008). How has grief tourism re-defined the social and judicial progress of the Madres de Plaza de Mayo? (Doctoral dissertation, Texas A\&M University).

Trauer, B. (2006). Conceptualizing special interest tourism-frameworks for analysis. Tourism Management, 27(2), 183-200.

Tuncer, N. ve Aksoy, A. B. (2017). Üniversite Öğrencileri ile Anne-Babaları Arasındaki ilişkinin Taraflar Açısından İncelenmesi: Nitel Bir Analiz, International Journal of Eurasia Social Sciences, 8 (26), 176-202.

Tzanelli, R. (2016). Thana tourism and the Cinematic Respresantation of Risk. Abingdon: Routledge.

Uzunaslan, A. (2005). Antik Roma' da Gladyatör Oyunları, Sosyal Bilimler Dergisi, (12), 15-58.

Yeşildă̆, B. (2010). Savaş alanları turizmi: Gelibolu Yarımadası Tarihi Milli Parkı Örneği (Yüksek Lisans Tezi, Çanakkale Onsekiz Mart Üniversitesi Sosyal Bilimler Enstitüsü).

Yıldırım, A. ve Şimşek, H. (2013). Sosyal Bilimlerde Nitel Araştırma Yöntemleri (9. Genişletilmiş Baskı). Ankara: Seçkin Yayınevi.

Yıldız, Z., Yıldız, S., ve Aytemiz, L. (2015). Kara Turizm, Terör Turizmi ve Türkiye Potansiyeli. İnsan ve Toplum Bilimleri Araştırmaları Dergisi, 4(2), 390-407.

Zhang, J. J. (2010). Of Kaoliang, bullets and knives: Local entrepreneurs and the battlefield tourism enterprise in Kinmen (Quemoy), Taiwan. Tourism Geographies, 12(3), 395-411. 